\title{
ATP Binding Cassette Transporter A1 is Involved in Extracellular Secretion of Acetylated APE1/Ref-1
}

\author{
Yu Ran Lee ${ }^{\oplus}$, Hee Kyoung Joo, Eun Ok Lee, Hyun Sil Cho, Sunga Choi $\oplus^{\circ}$, Cuk-Seong Kim and \\ Byeong Hwa Jeon *
}

Research Institute of Medical Sciences, Department of Physiology, College of Medicine, Chungnam National University, 266 Munhwa-ro, Jung-gu, Daejeon 35015, Korea

* Correspondence: bhjeon@cnu.ac.kr; Tel.: +82-42-580-8214; Fax: +82-42-585-8440

Received: 27 April 2019; Accepted: 26 June 2019; Published: 28 June 2019

\begin{abstract}
Acetylation of nuclear apurinic/apyrimidinic endonuclease-1/redox factor-1 (APE1/Ref-1) is associated with its extracellular secretion, despite the lack of an $\mathrm{N}$-terminal protein secretion signal. In this study, we investigated plasma membrane targeting and translocation of APE1/Ref- 1 in HEK293T cells with enhanced acetylation. While APE1/Ref-1 targeting was not affected by inhibition of the endoplasmic reticulum/Golgi-dependent secretion, its secretion was reduced by inhibitors of ATP-binding cassette $(\mathrm{ABC})$ transporters, and siRNA-mediated down-regulation of $\mathrm{ABC}$ transporter A1. The association between APE1/Ref- 1 and ABCA1 transporter was confirmed by proximal ligation assay and immunoprecipitation experiments. An APE1/Ref- 1 construct with mutated acetylation sites (K6/K7R) showed reduced co-localization with $A B C$ transporter A1. Exposure of trichostatin A (TSA) induced the acetylation of APE1/Ref-1, which translocated into membrane fraction. Taken together, acetylation of APE1/Ref-1 is considered to be necessary for its extracellular targeting via non-classical secretory pathway using the ABCA1 transporter.
\end{abstract}

Keywords: APE1/Ref-1; Acetylation; Secretion; Non-classical pathway; ABCA1 transporter

\section{Introduction}

Cells can dynamically communicate with the extracellular environment via secretory molecules. The secreted molecules can act as para- or autocrine factors in cell signaling and gene expression $[1,2]$. The two major pathways for secreting proteins across the plasma membrane in eukaryotes are the classical (endoplasmic reticulum (ER)/Golgi-dependent) and non-classical (endoplasmic reticulum (ER)/Golgi-independent or unconventional) pathways. Identification of the non-classical pathway was based on the observation that communication with neighboring cells via extracellular secretion of signaling proteins can occur even in absence of a signal peptide, an $\mathrm{N}$-terminal extension sequence, or the ER membrane translocation machinery. Signaling molecules that are secreted via the non-classical pathway include: fibroblast growth factor-2 (FGF-2), an angiogenesis stimulant essential for tumor growth and metastasis [3]; galectin-1, an inducer for tumor-mediated immune suppression [4]; and cytokine interleukin-1 $\beta$ (IL-1 $\beta$ ) from activated macrophages, a mediator of the inflammatory response involved in cell proliferation, differentiation, and apoptosis [5].

The apurinic/apyrimidinic endonuclease-1/redox factor-1 (APE1/Ref-1), a typical nuclear protein with a pleiotropic role in oxidative stress response, has also been found in the mitochondria of metabolically active and proliferative cells [6,7]. Recent studies have indicated that APE1/Ref-1, which is localized in the cytoplasm, is susceptible to post-translational modification (PTM), such as nitrosylation or acetylation [8,9]. Interestingly, APE1/Ref-1 protein secretion showed remarkable regulatory effects on inflammatory cytokine-stimulated cells both in vitro and in vivo [10-12]. Moreover, in different tumor cell types, the level of APE1/Ref-1 was abnormally high $[13,14]$, suggesting its 
possible use as a cancer biomarker. The different subcellular distribution of APE1/Ref- 1 and the evidence of its extracellular secretion together suggest that its distribution and translocation are controlled not only by stimulatory agents like chemicals or hormones but also by plasma membrane transporters. Although APE1/Ref-1 has been demonstrated to accumulate along the plasma membrane in the presence of a deacetylase inhibitor, trichostatin A (TSA) [15], the mechanism of its translocation across the plasma membrane remains unknown.

In this study, we hypothesized that APE1/Ref- 1 is secreted by a membrane transporter since its plasma membrane translocation depends on PTM [16-18], and appears to be controlled by extracellular factors whose identities are still under investigation. To identify the transporter pathway for APE1/Ref-1, we used pharmacological inhibitors that prevent the secretion of intracellular proteins by targeting specific transporters, such as the $A B C$ transporter $A 1$ (ABCA1). In the present study, we established the identity of the transport pathway for APE1/Ref-1 and our results will facilitate the analysis of the extracellular roles of this multifunctional protein.

\section{Results}

\subsection{Non-Classical Secretion of APE1/Ref-1 in Response to TSA}

Initially, we determined the secretion of APE1/Ref-1 in trichostatin A (TSA)-treated HEK293T cells. The amount of secreted APE1/Ref-1 in culture supernatant, in response to deacetylase inhibitor, was quantitatively analyzed by enzyme-linked immunosorbent assay (ELISA), and the cell viability was analyzed by RealTime-Glo ${ }^{\mathrm{TM}}$ MT assay to exclude the possibility of contamination from cell cycle progression. The results are summarized in Figure 1A,B. TSA concentrations used in the present study were within the range used previously to document the acetylation of intracellular proteins [9], without affecting the viability of HEK293T cells (Figure 1B). Interestingly, TSA-treated cells showed an increase in APE1/Ref-1 secretion (total amount of APE1/Ref-1, $0.85 \pm 0.06 \mathrm{ng} / 2 \times 10^{5}$ cells) compared to the control cells (total amount of APE1/Ref-1, $0.07 \pm 0.01 \mathrm{ng} / 2 \times 10^{5}$ cells) (Figure 1A). Since TSA induced APE1/Ref-1 secretion, we examined the effects of secretory pathway inhibitors on its secretion. Pre-exposure of TSA-treated HEK293T cells to brefeldin A (BFA), an inhibitor of the ER-to-Golgi classical transport pathway, had no effect on Ac-APE1/Ref-1 secretion (Figure 1C), whereas TNF- $\alpha$ secretion, which depends on the classical secretory pathway, was abrogated (Figure 1D). These results together indicated that TSA treatment increased APE1/Ref-1 secretion via non-classical transport pathways. 
A

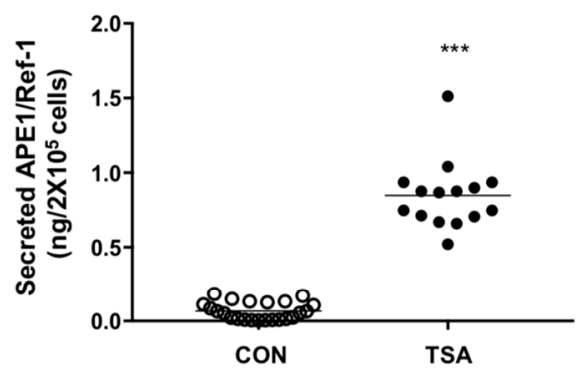

C

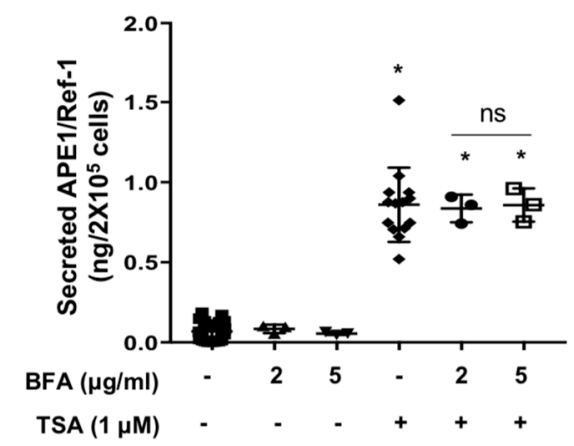

B

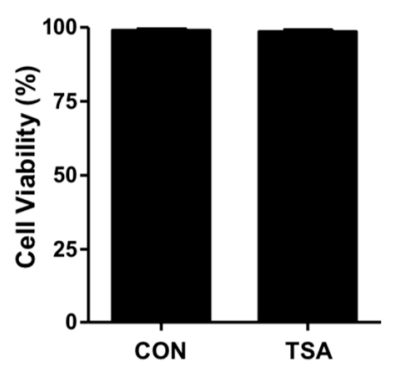

D

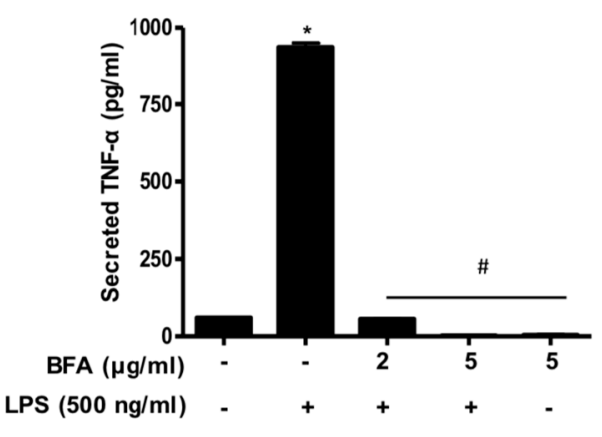

Figure 1. Secretion of APE1/Ref-1 was mediated by the non-classical pathway. (A) HEK293T cells were treated with $1 \mu \mathrm{M}$ trichostatin A (TSA) for $1 \mathrm{~h}$ prior to collecting the cell-free supernatant. The total extracellular secretion of APE1/Ref-1 from acetylated HEK293T cells was measured by ELISA. Columns, mean $(n=15-20)$; dot plot, SE. ${ }^{* * *} p<0.001$ indicates a significantly different result from control cells according to an unpaired $t$-test. (B) Effects of TSA on the viability of HEK293T cells were determined using a bioluminescent assay Columns, mean $(n=6)$; bars, non- significantly different from control cells according to an unpaired $t$-test. (C) HEK293T cells were pretreated with brefeldin A (BFA), a classical secretory pathway inhibitor, followed by $1 \mu \mathrm{M}$ TSA treatment for $3 \mathrm{~h}$. The total amount of secreted Ac-APE1/Ref-1 in cell-free supernatant was analyzed by ELISA. (D) The total amount of secreted TNF- $\alpha$ from LPS-stimulated RAW 264.7 cells before exposure to BFA at the indicated concentration. Column, mean $(n=5)$; bars, SE. ${ }^{*}, *, p<0.05$ indicates a significantly different result compared with control or between groups by one-way ANOVA followed by Bonferroni's multiple comparison test.

\subsection{Extracellular Secretion of APE1/Ref-1 Was Decreased by ABC Transporter Inhibitors}

$A B C$ transporters were used to transport a variety of substrates across cell membrane including ions, lipid, amino acids, even proteins [19]. As established APE1/Ref- 1 secretion is mediated with non-classical transport pathway, we focused on the effect of an ABC transporter on APE1/Ref-1 secretion in TSA-treated HEK293T cells. As shown in Figure 2A, the secretion of APE1/Ref-1 from TSA-treated HEK293T cells was affected when the cells were pre-exposed to probenecid, a broad-spectrum inhibitor of ABC transporters. Probenecid-pretreated cells stimulated with TSA $\left(0.39 \pm 0.02 \mathrm{ng} / 2 \times 10^{5}\right.$ cells $)$ showed significantly inhibited APE1/Ref- 1 secretion compared to TSA-only-stimulated cells $(0.85 \pm$ $0.06 \mathrm{ng} / 2 \times 10^{5}$ cells). As shown in Figure 2C, interestingly, APE1/Ref-1 secretion was also significantly reduced by more than $50 \%$ after pretreatment with glyburide $[20,21]$, a selective inhibitor of $A B C$ transporters such as ABCA1, $\mathrm{ABCB} 1, \mathrm{ABCB} 11, \mathrm{ABCC} 1, \mathrm{ABCC} 2, \mathrm{ABCC} 3, \mathrm{ABCC} 8$, and $\mathrm{ABCC}$ [22-27]. The exposure of two inhibitors did not affect cell viability, as shown in Figure 2B,D, respectively. These 
results strongly suggested that secretion of APE1/Ref-1 in TSA-treated HEK293T cells depends on the non-classical secretory pathway involving $\mathrm{ABC}$ transporters.

A

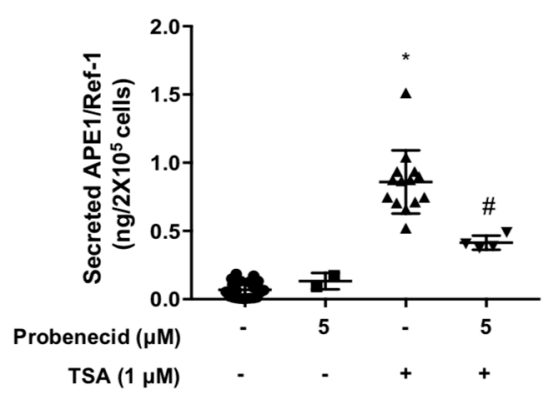

C

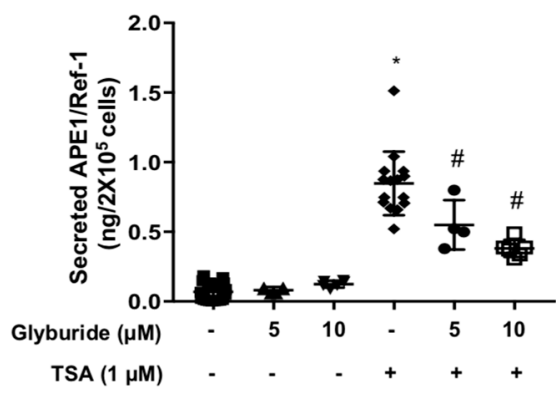

B

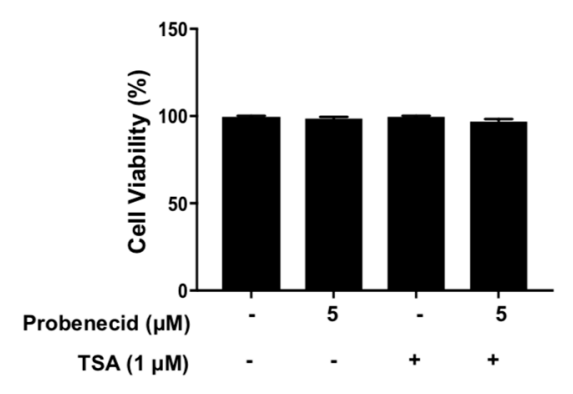

D

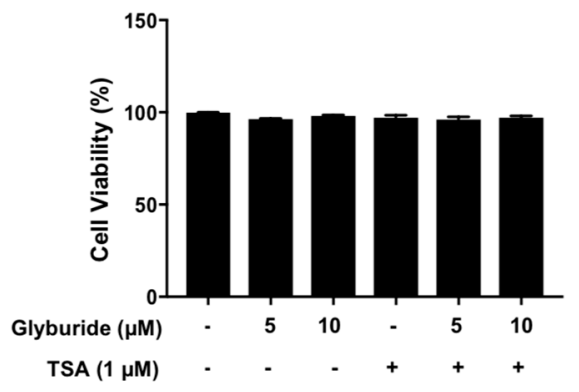

Figure 2. Secretion of APE1/Ref-1 was decreased by ABC transporter inhibitors. Quantitative analysis of Ac-APE1/Ref-1 secretion in the presence of pharmacological inhibitors. (A) Probenecid or (C) glyburide, non-classical secretory pathway inhibitors, for $1 \mathrm{~h}$ at the indicated concentrations, followed by $1 \mu \mathrm{M}$ TSA treatment for $3 \mathrm{~h}$. Column mean $(n=4-5)$; dot plot, SE. ${ }^{* * *}, p<0.001$ indicates a significantly different result compared with control or between group by one-way ANOVA followed by Bonferroni's multiple comparison test. The total amount of secreted Ac-APE1/Ref-1 in cell-free supernatant was analyzed by ELISA. (B,D) Effect of inhibitor and TSA on the viability of HEK293T cells were determined using a bioluminescent assay. Column mean $(n=4-5)$; bars, SE. $*$,\#, $p<0.05$ indicates a significantly result different compared with control or between groups by one-way ANOVA followed by Bonferroni's multiple comparison test.

\subsection{ABCA1 Transporter Was Involved in the Secretion of APE1/Ref-1}

To identify the $A B C$ transporter responsible for the secretion of APE1/Ref-1, we determined the presence of ABC transporters in HEK293T cells. Expression of ABCA1, ABCB1, ABCC1, ABCC2, and ABCC8 transporters were detected in the HEK293T cells (Figure 3A). We proceeded to determine the functional significance of each ABC transporter in TSA-treated HEK293T cells using siRNA. Transient transfection of each $A B C$ transporter-targeted siRNA resulted in selective and significant abrogation of the respective $A B C$ transporter (Figure 3B left panel). Importantly, specific knockdown of ABCA1 without affecting the expression of other subtypes (Figure 3B right panel), caused significant inhibition of APE1/Ref-1 secretion in HEK293T cells, despite the TSA treatment; from $0.96 \mathrm{ng} / 2 \times 10^{5}$ cells in TSA-treated cells to $0.42 \mathrm{ng} / 2 \times 10^{5}$ cells in ABCA1 knockdown TSA-treated cells (Figure 3C). The latter amount was comparable to values obtained in other control cells. Knockdown of other $A B C$ transporters did not significantly affect APE1/Ref-1 secretion. In summary, these results indicated 
that the ABCA1 transporter was mainly required for the extracellular secretion of APE1/Ref- 1 in TSA-treated HEK293T cells.

A

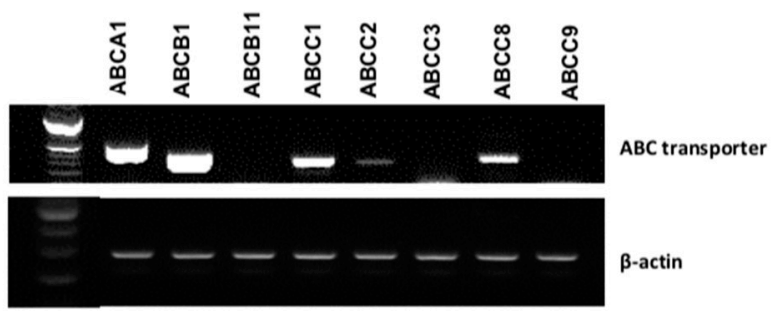

B

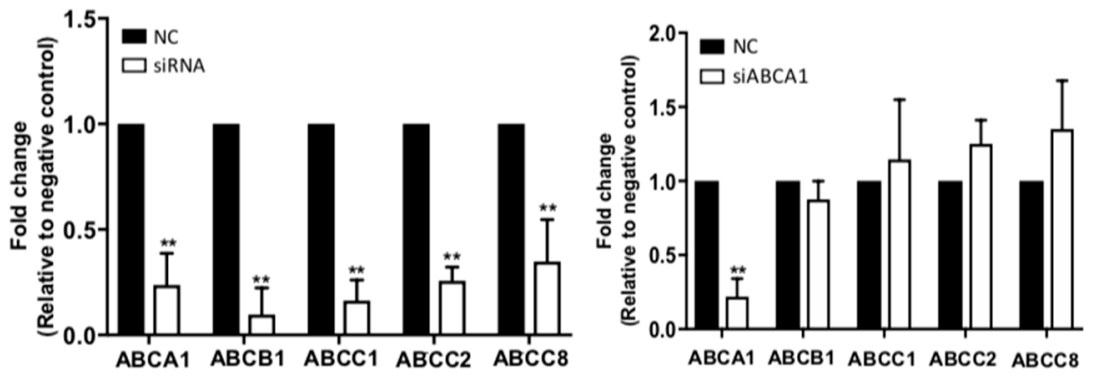

C

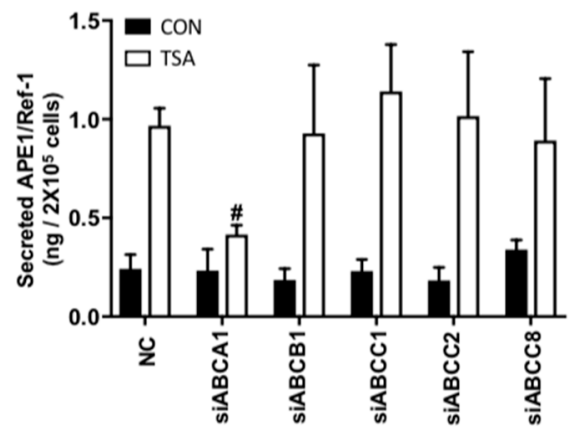

Figure 3. ATP binding cassette transporter A1 (ABCA1) was involved in the secretion of APE1/Ref-1. (A) The subfamily of ABC transporter expressed in HEK293T cells. The qRT-PCR analysis for ABC transporters using lysates from HEK293T cells. $\beta$-actin was tested in parallel and normalized an equal amounts of total RNA per sample. (B) The subfamily of ABC transporter expressed in HEK293T cells transiently transfected with siRNA. (Left) The qRT-PCR analysis for knock-down of ABC transporters in transfected cells with each siRNA. (Right) mRNA level of each ABC transporters were analyzed using qRT-PCR in siABCA1 transfected cells. Columns, mean $(n=3)$; bars, SE. ${ }^{* *} p<0.01$ indicated a significantly different result from non-specific siRNA (NC) transfected cells by two-way ANOVA followed by Bonferroni's multiple comparison test. (C) Changes in the total amount of secreted Ac-APE1/Ref-1 from cells after knock-down of each ABC transporter were analyzed using ELISA. Columns, mean $(n=3)$; bars, SE. ${ }^{\#} p<0.05$ indicated a significantly different result from TSA treated cells or between groups by two-way ANOVA followed by Bonferroni's multiple comparison test.

\subsection{Acetylation of APE1/Ref-1 Was Required for Binding to ABCA1 Transporter}

We next tested whether the acetylation of APE1/Ref-1 was specifically required for both the binding to ABCA1 transporter and subsequent translocation of the protein to the exterior of the cell. We examined the role of acetylation using two different, yet complementary approaches. We first 
performed a co-immunoprecipitation experiment to confirm that APE1/Ref-1 was directly associated with the ABCA1 transporter. Acetylation of intracellular proteins by TSA treatment enabled the binding of exogenously overexpressed APE1/Ref-1-FLAG to the ABCA1 transporter, as demonstrated by the pull-down of FLAG-tagged APE1/Ref-1 protein using anti-ABCA1 transporter antibody. However, a less acetylated mutant form, the exogenously overexpressed APE1/Ref-1 (K6/7R)-FLAG, was not co-immunoprecipitated using anti-ABCA1 transporter antibody despite the stimulation of acetylation after TSA treatment (Figure 4A). Conversely, the binding of APE1/Ref-1 to ABCA1 was also confirmed by co-immunoprecipitation with anti-APE1/Ref-1 antibody; we observed that acetylation of APE1/Ref-1 was required for the interaction with ABCA1 (Figure 4B). The Duolink II cell-based fluorescent proximal ligation assay (PLA) was used to visualize the direct binding of APE1/Ref-1 to ABCA1. TSA-treated HEK293T cells, expressing wild- type APE1/Ref-1-FLAG, were incubated with a mixture of anti-APE1/Ref-1 and anti-ABCA1 antibodies. The association of APE1/Ref-1 with ABCA1 was visualized by numerous red spots, indicating a proximal interaction between APE1/Ref- 1 and ABCA1 transporter ( $<40 \mathrm{~nm}$ ). In contrast, TSA-treated HEK293T cells, expressing mutant APE1/Ref-1(K6/7R)-FLAG, showed only weak background signals. These results demonstrated that APE1/Ref-1 directly interacted with ABCA1 transporter as a prerequisite for its secretion in TSA-treated HEK293T cells (Figure 4C). This result was also supported by comparing the efficient co-immunoprecipitation of wild-type APE1/Ref-1-FLAG with ABCA1.

\subsection{Intracellular Acetylation Induced APE1/Ref-1 Translocation to the Plasma Membrane}

Next, we examined whether APE1/Ref-1 can be acetylated with TSA, and the trafficking of acetylated APE1/Ref-1(Ac-APE1/Ref-1) to the plasma membrane in HEK293T cells. Acetylation of APE1/Ref-1 in the response of TSA was analyzed with immunoblotting of APE1/Ref-1 after immunoprecipitation using anti-acetyl-lysine antibody (Figure 5A). TSA-treated cells showed about 4-fold higher quantities of Ac-APE1/Ref-1, compared with control cells (Figure 5B). Finally, we proceeded to examine the trafficking of APE1/Ref-1 to the plasma membrane in TSA-treated HEK293T cells. As shown in Figure 5C, TSA-induced APE1/Ref-1 enrichment was detected in the plasma membrane fraction and was confirmed using an anti-N-cadherin antibody. TSA-treated cells had an approximately 3-fold higher content of plasma membrane-located APE1/Ref-1 compared to the control cells (Figure 5D). 
A
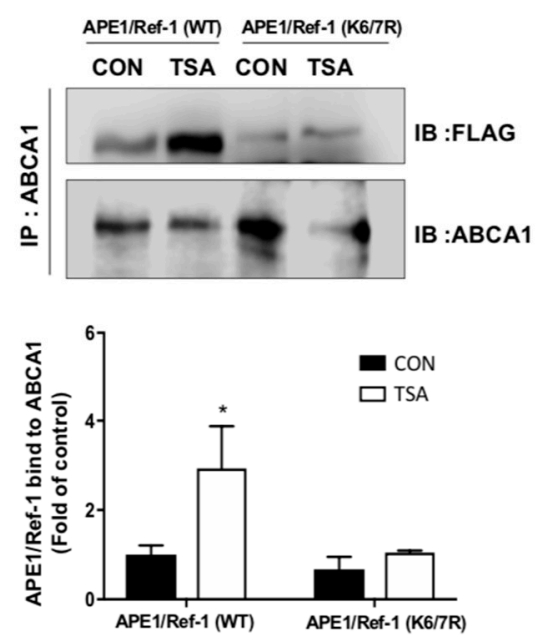

C

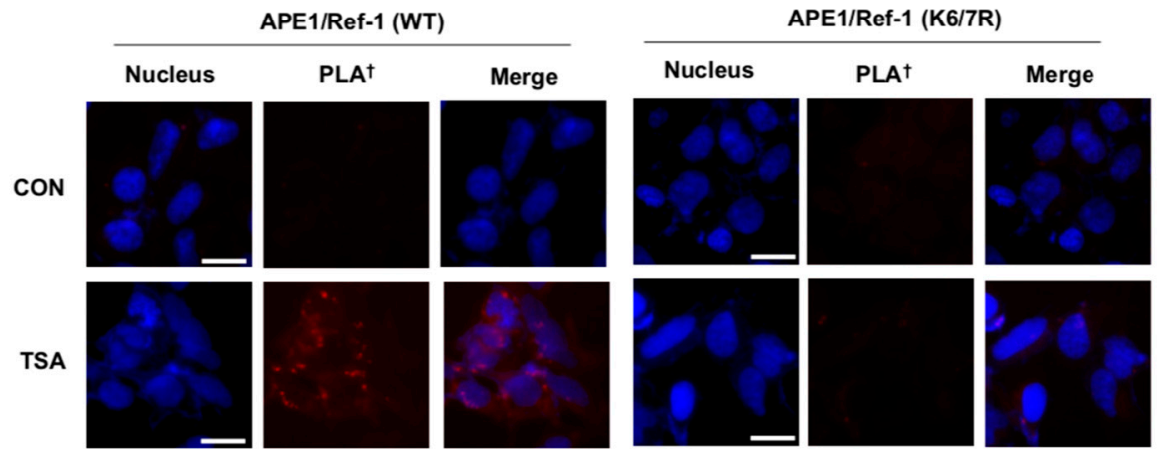

Figure 4. Plasma membrane associated APE1/Ref-1 is bound to ABCA1 in response to acetylation. Cells transiently expressing wild type APE1/Ref-1-FLAG or mutant APE1/Ref-1(K6/7R)-FLAG were treated with $1 \mu \mathrm{M}$ TSA for $1 \mathrm{~h}$. (A) Whole cell lysates were immunoprecipitated using the monoclonal anti-ABCA1 antibody, followed by immunoblot with the anti-FLAG antibody. (B) For reverse immunoprecipitation, cell lysates were immunoprecipitated with anti-APE1/Ref-1 antibody followed by immunoblot analysis with the polyclonal anti-ABCA1 antibody. Blots were stripped and re-probed with anti-ABCA1 or FLAG antibodies to ensure equal protein loading and no contamination of cellular proteins. Similar results were observed in replicate experiments. Columns, mean $(n=2-3)$; bars, SE. *, $p<0.05$ indicates a significantly different result from control cells according to unpaired $t$-tests. (C) The binding between APE1/Ref-1 and ABCA1 in the plasma membrane was visualized using with a Duolink II PLA system with primary polyclonal anti-APE1/Ref-1 and monoclonal anti-ABCA1 antibodies $\left(\mathrm{PLA}^{\dagger}\right)$. The PLA-specific fluorescence which represents the APE1/Ref-1-ABCA1 signal, and the DAPI nuclear staining are in red and blue, respectively. The experiment was repeated multiple times with similar results; the data shown here are from a representative experiment. Optical slices were examined using a $40 \times$ oil immersion objective with a $2 \times$ zoom factor. Scale bar, $20 \mu \mathrm{m}(\times 80)$. 
A

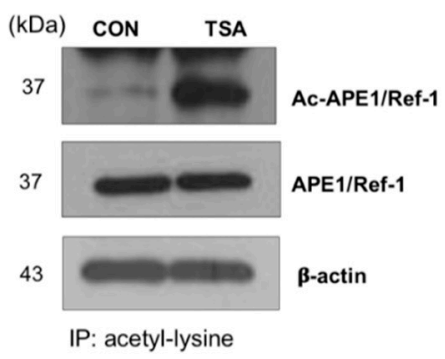

C

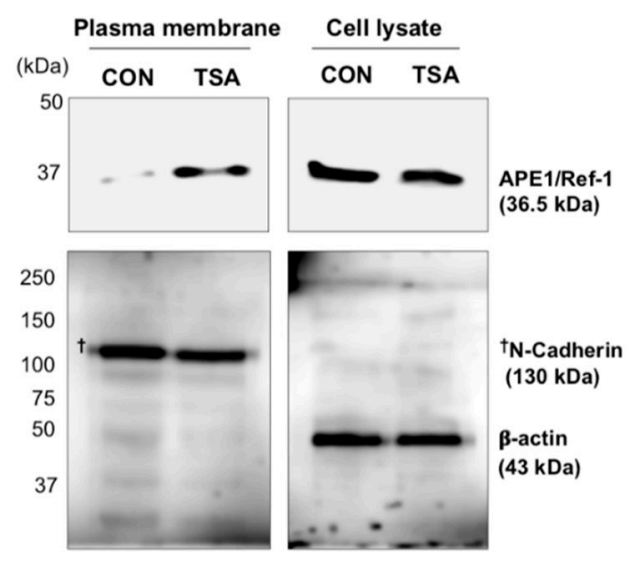

B

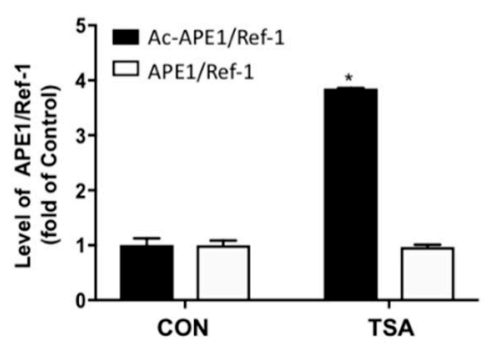

D

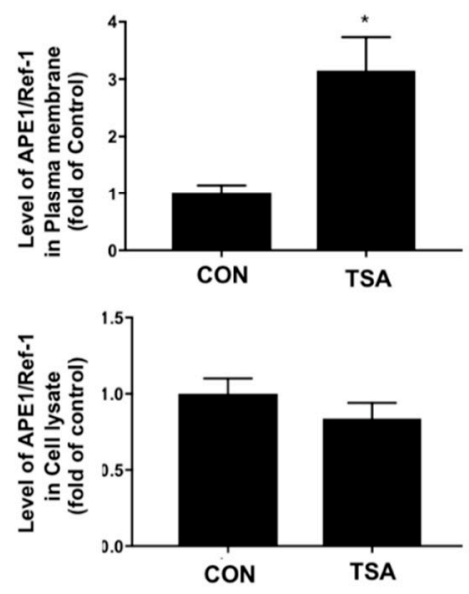

Figure 5. Intracellular APE1/Ref-1 was targeted to the plasma membrane in response to acetylation. $(\mathbf{A}, \mathbf{B})$ Whole cell lysates were immunoprecipitated using an anti-acetyl lysine antibody, followed by immunoblotting with the polyclonal anti-APE1/Ref- 1 antibody. The blots were stripped and re-probed with anti- $\beta$-actin and APE1/Ref- 1 antibody to ensure equal protein loading. Similar results were obtained from replicate experiments. Column, mean $(n=3)$; bars, SE. *, $p<0.05$, significantly different compared with control or between group by one-way ANOVA followed by Bonferroni's multiple comparison test. (C,D) Membrane fractions or whole cell lysates were prepared from the TSA-treated cells. Immunoblotting for APE1/Ref-1 was performed using the polyclonal anti-APE1/Ref-1 antibody. Blots were stripped and re-probed with anti-N-cadherin and anti- $\beta$-actin antibodies to control for differences in protein loading. Fold changes in the levels of APE1/Ref- 1 in the plasma membrane fraction relative to the control are shown. ${ }^{\dagger}$, indicates molecular marker ( $\mathrm{N}$-cadherin) of left image. Column mean $(n=3)$; bars, SE. ${ }^{*}, p<0.05$ indicates a significantly different result compared with control or between groups by one-way ANOVA followed by Bonferroni's multiple comparison test.

\section{Discussion}

Previous studies have demonstrated that APE1/Ref-1, a typical nuclear protein, is also present in the extracellular milieu of cells associated with chronic diseases [11,13,28-30]. Identification of its secretory pathway would clarify whether the detection of APE1/Ref-1 in extracellular samples is an experimental artifact or is the result of a controlled cellular response to certain stimulators. The major finding of this study was that APE1/Ref-1 is secreted from cells stimulated for protein acetylation via a non-classical secretory pathway that involves ABCA1 transporter. Since probenecid and glyburide treatment caused significant inhibition of Ac-APE1/Ref-1 secretion, suggesting the involvement of a non-classical secretory pathway with $\mathrm{ABCA} 1$ transporter, we focused on $\mathrm{ABCA} 1$ as a transporter candidate based on the following experimental data: (i) dominant expression in HEK293T cells, (ii) transporter-specific pharmacological inhibition, and (iii) knock-down using specific ABCA1 siRNA. 
These observations strongly supported the possibility of involvement of ABCA1 in the secretion of Ac-APE1/Ref-1.

Some studies have suggested that protein translocation mediated by $\mathrm{ABC}$ transporters requires protein unfolding, which is a general prerequisite for protein translocation complexes across membranes [31,32]. However, some non-classical secretion of FGF-2 and Gal-1 does not require protein unfolding [33,34]. ABCA1 is a membrane protein, and affects secretion of various proteins such as the macrophage migration inhibitory factor (MIF) and interleukin-1beta (IL-1 $\beta$ ) [20,26]. Moreover, the direct involvement of $\mathrm{ABC}$ transporters has been demonstrated for lipid transport [35], such as vesicle export [36]. In a previous study, TSA-mediated acetylation was shown to cause PTM of APE1/Ref-1 (30 Lys residues in APE1/Ref-1), attaching an acetyl group to the $\varepsilon$-amino group of lysine residues [37]. Acetylation reduces the net charge and increases the hydrophobicity of APE1/Ref-1 [38]. In the present study, APE1/Ref-1 secretion was not limited with HDAC inhibitor TSA. HDAC inhibitors such as SAHA, valproic acid, and butyrate also induced APE1/Ref-1 secretion which was inhibited by glyburide (Supplementary Figure S1). Pharmacological inhibitions of probenecid and glyburide on APE1/Ref-1 secretion suggested a possible involvement of ABC transporters. Sulfonylurea such as glyburide used for the treatment of diabetes mellitus inhibits a variety of $\mathrm{ABC}$ transporters, including ABCA1 [22-27], the specificity of glyburide for each ABC transporters should be carefully considered. In the present study, we have confirmed that the expression of $A B C A 1, A B C B 1, A B C C 1, A B C C 2$, and ABCC 8 transporters were detected in the HEK293T cells. Specific knockdown of ABCA1 without affecting the expression of other ABC transporters caused significant inhibition of APE1/Ref- 1 secretion in HEK293T cells. Our study is the first to describe the extracellular secretion of Ac-APE1/Ref- 1 by ABCA1 in response to acetylation. However, it is still unknown how ABCA1 transports APE1/Ref-1. It is necessary to further research APE1/Ref-1 secretion in response to specific stimuli such as an endogenous hormone.

Intracellular imbalance can influence the interplay between survival pathways and cell death, causing cell cycle arrest, re-differentiation, or metabolic reprogramming. Intracellular imbalance is increased under inflammatory conditions associated with lung disease [39], vascular disease [40], hemorrhage, and sepsis [41], acetylation combined with coordinated expression of multiple inflammatory genes. Considering these reports, TSA-mediated acetylation in this study is an important observation for explaining the export of intracellular APE1/Ref- 1 . Recently, we have shown that APE1/Ref-1 is extracellularly secreted in an LPS-stimulated endotoxemic rat model [11]. The extracellular APE1/Ref-1 plays the role in disulfide bond exchange within the TNF receptor, causing inhibition of vascular inflammatory signals [10]. Stimulation of the APE1/Ref-1 secretion is triggered by its acetylation, as shown by diminished secretion level of the mutant APE1/Ref-1(K6/7R) due to mutated lysine, thus supporting the critical role played by lysine acetylation in various cardiovascular diseases [28]. Although deacetylation of Ac-APE1/Ref-1 followed time-dependent kinetics, eventually reaching an optimum, the recovery mechanism of Ac-APE1/Ref-1 to its non-acetylated form with respect to its reductase activity requires further studies. These observations raised the question of whether secreted APE1/Ref- 1 can be influenced in an extracellular inflammatory environment. These results also suggested that extracellular APE1/Ref-1 with redox activity could be considered for further clinical investigation to determine its possible therapeutic efficacy against chronic inflammation, owing to its potential role in the early prevention of inflammatory signals in vivo.

In summary, our current study indicated that the extracellular secretion of APE1/Ref-1 depends on acetylation, a common PTM in eukaryotic cells. Ac-APE1/Ref-1 is intracellularly targeted to the plasma membrane and translocated by $\mathrm{ABCA} 1$ membrane transporter for secretion into the extracellular milieu. 


\section{Materials and Methods}

\subsection{Materials}

TSA, brefeldin A (BFA), glyburide, probenecid, suberoylanilide hydroxamic acid (SAHA), valproic acid, butyrate and lipopolysaccharide (LPS) were purchased from Sigma Aldrich (St. Louis, MO, USA). Lipofectamine ${ }^{2}$ RNAiMAX, Opti-MEM ${ }^{\mathrm{TM}}$ media, and Dynabeads ${ }^{\circledR}$ Magnetic beads were purchased from Thermo Fisher Scientific (San Jose, CA, USA). ABCA1 small interfering RNA (siRNA), control siRNA, and primers were purchased from Bioneer (Daejeon, Korea). Complementary DNA synthesis kit and PCR PreMix kit were purchased from Intron biotechnology Inc. (Seongnam, Gyeonggi-do, Korea). Mouse tumor necrosis factor (TNF)- $\alpha$ ELISA kit was purchased from R\&D system (Minneapolis, MN, USA). Anti-N-cadherin antibody was purchased from Abcam (cat.no. ab18203, Cambridge, MA, USA); anti- $\beta$-actin antibody was purchased from Sigma Aldrich (cat.no. A5316, St. Louis, MO, USA); Monoclonal anti-ABCA1 antibody (cat.no. sc-58219, Santa Cruz Biotechnology, Santa Cruz, CA, USA) and polyclonal antibody (cat.no. PA1-16789, Invitrogen, Waltham, MA, USA) were used. Monoclonal (cat.no. NB100-116, Novus Biologicals, Littleton, CO, USA) and polyclonal antibodies against APE1/Ref-1 (cat.no. MR-PAAPE, MediRedox, Daejeon, Korea) were used.

\subsection{Cell culture and treatment}

Human embryonic kidney 293T (HEK293T) cells and Raw 264.7 cells were cultured in Dulbecco's modified Eagle's medium (Welgen, Korea) with 10\% fetal bovine serum and 1\% antibiotics. Each cell line was incubated under humid conditions at $37^{\circ} \mathrm{C}$ and $5 \% \mathrm{CO}_{2}$. Cells were seeded into well plates and incubated for 24 hours, followed by replacement of the culture medium with Opti-MEM ${ }^{\mathrm{TM}}$. The cells were treated with the inhibitor for $2 \mathrm{~h}$, followed by TSA treatment for $1 \mathrm{~h}$, as indicated. Cell viability was analyzed using the RealTime-Glo ${ }^{\mathrm{TM}}$ MT luminescent kit (Promega, Madison, WI, USA) in an opaque-walled assay plate, according to the manufacturer's instructions and as reported previously [42].

\subsection{Enzyme-linked immunosorbent assay (ELISA)}

The amount of APE1/Ref-1 in each sample was determined by ELISA analysis (MediRedox, Daejeon, Korea) [43]. HEK293T cells were grown to confluence on a 12 -well plate $\left(2 \times 10^{5}\right.$ cells/well $)$ and then changed with Opti-MEM ${ }^{\mathrm{TM}}$ medium. Then, the cells were treated with $1 \mu \mathrm{M}$ TSA in $0.5 \mathrm{~mL}$ Opti-MEM ${ }^{\mathrm{TM}} /$ well, and to obtain cell-free supernatant, the medium was collected by centrifugation at $1200 \mathrm{rpm}$ for $3 \mathrm{~min}$. Supernatant without cell debris was carefully recovered and re-centrifuged at 3000 rpm for $3 \mathrm{~min}$. The final supernatant was used for detection of secretory APE1/Ref-1. Each sample was assayed in duplicate.

For the measurement of TNF- $\alpha$ concentrations in the cell culture medium, the supernatant was obtained from LPS (300 ng/ml)-treated Raw 264.7 cells. The level of TNF- $\alpha$ was determined using a mouse TNF- $\alpha$ ELISA kit (BD Pharmingen, San Diego, CA, USA).

\subsection{Transfection of small interfering RNA (siRNA)}

To evaluate the efficiency of ABC transporters gene silencing, HEK293T cells $\left(2.5 \times 10^{5}\right.$ cells/well) were transfected with a range of $20 \mathrm{nM}$ ABC transporters siRNA (Bioneer Inc., Daejeon, Korea) or 20 nM control siRNA using Lipofectamine ${ }^{\circledR}$ RNAiMAX according to the manufacturer's protocol. The siRNA sequence of ABC transporters is shown in Table 1. 
Table 1. The siRNA sequences of ABC transporters.

\begin{tabular}{ccc}
\hline Target Gene & Accession No. & siRNA sequence $\left(\mathbf{5}^{\prime}-\mathbf{3}^{\prime} \mathbf{)}\right.$ \\
\hline$A B C A 1$ & NM_005502 & GUGUCUAUAUGCAACAGAU \\
$A B C B 1$ & NM_000927 & CAGCAAUUAGAACUGUGAU \\
$A B C C 1$ & NM_004996 & CUGACAAGCUAGACCAUGA \\
$A B C C 2$ & NM_000392 & ACAAGGUAAUGGUCCUAGA \\
$A B C C 8$ & NM_000352 & CGUCAUCUCCUAUGUCACA \\
\hline
\end{tabular}

\subsection{Quantitative Real-Time Reverse Transcription-Polymerase Chain Reaction ( $q$ RT-PCR)}

Total RNA from the HEK293T cells was extracted using NucleoSpin RNA Plus (Machery-Nagel Inc, Bethlehem, PA, USA) following manufacturer's protocol. Complementary DNA (cDNA) was synthesized by reverse transcription-PCR kit (iNtRON Biotechnology, Gyeonggi-do, Korea) with primers [44]. The primers for human ABC transporters used in this study are shown in Table 2. The mRNA levels of ABC transporters were determined by qRT-PCR using SYBR Green PCR Master Mix (Promega, Madison, WI, USA) according to the protocols provided by the manufacturer with an ABI prism 7700 Sequence Detector System (Applied Biosystems, CA, USA). Target gene mRNA expression levels were calculated using the $\Delta C$ t method and normalized to glyceraldehyde 3-phosphate dehydrogenase mRNA expression.

Table 2. The primers for glyburide-sensitive human ABC transporters.

\begin{tabular}{cccccc}
\hline $\begin{array}{c}\text { Target } \\
\text { Gene }\end{array}$ & Accession No. & Forward $\left(5^{\prime}-\mathbf{3}^{\prime}\right)$ & Reverse $\left(\mathbf{5}^{\prime}-\mathbf{3}^{\prime}\right)$ & $\begin{array}{c}\text { TM } \\
\left({ }^{\circ} \mathbf{C}\right)\end{array}$ & Cycle \\
\hline$A B C A 1$ & NM_005502 & actgtggacaagatgctgagg & aaacatcacctcctgtcgcat & 60 & 25 \\
\hline$A B C B 1$ & NM_000927 & cacaagcccaagacagaaagc & tgagcatggatcggaaaacca & 60 & 25 \\
\hline$A B C B 11$ & NM_003742 & gaagctgagcttggtcatctt & gcagagatcaccctgaacaca & 60 & 25 \\
\hline$A B C C 1$ & NM_004996 & tgctcactttctggctggtag & ccgacgtgtcctccttgttta & 60 & 25 \\
\hline$A B C C 2$ & NM_000392 & tgcggctctcattcagtcttt & atcaccccaacacctgctaag & 60 & 25 \\
\hline$A B C C 3$ & NM_003786 & cgtggctacatcatcctctcc & gtagaaggtggtgaagcggaa & 60 & 25 \\
\hline$A B C C 8$ & NM_000352 & atccccacactgtccaacatc & agagagcaggcttcaatgacc & 60 & 25 \\
\hline$A B C C 9$ & NM_020297 & caggacggattatctgggagc & tgatgtaagccttgacgtgct & 60 & 25 \\
\hline
\end{tabular}

\subsection{Fractionation of Plasma Membrane}

The plasma membrane of HEK293T cells, which had been transfected with ABCA1 siRNA, was prepared by sucrose density gradient centrifugation as described previously [15]. The membrane pellet was analyzed by immunoblotting using anti-ABCA1 and anti-N-cadherin antibodies.

\subsection{Immunoprecipitation}

To analyze the Ac-APE1/Ref- 1 in cell lysate, immunoprecipitation using anti-acetyl lysine antibody was performed as previously reported [15] with some modifications. Co-immunoprecipitation using monoclonal anti-ABCA1 antibody and polyclonal anti-APE1/Ref-1 was also performed to analyze the binding between ABCA1 and APE1/Ref-1 in cell lysate. Briefly, the one microgram of each antibodies was added to cell lysate and incubated for $2 \mathrm{~h}$ at $4{ }^{\circ} \mathrm{C}$. Protein A/G agarose beads were then added to each sample and incubated for $18 \mathrm{~h}$ at $4{ }^{\circ} \mathrm{C}$. The immunocomplex was collected using centrifugation at $300 \mathrm{rpm}$ for $3 \mathrm{~min}$ and washed three times in washing buffer. Each sample was subjected to 10 12\% SDS-PAGE, which was followed by immunoblotting using monoclonal anti-APE1/Ref-1 antibody and polyclonal anti-ABCA1 antibody. 


\subsection{Proximal Ligation Assay}

Interaction of ABCA1 and APE1/Ref-1 was visualized using a Duolink II fluorescence kit (Sigma-Aldrich, St Louis, MO, USA) as described previously [15], with some modifications. HEK293T cells expressing wild type APE1/Ref-1-FLAG [45] or mutant APE1/Ref-1(K6/7R)-FLAG [46] grown on glass coverslips were treated with TSA for $1 \mathrm{~h}$. After fixation and blocking the cells were incubated with a mixture of goat anti-ABCA1 antibody (1:200) and rabbit anti-APE1/Ref-1 antibody (1:500) overnight at $4{ }^{\circ} \mathrm{C}$. For in situ analysis, conjugated oligonucleotides [PLA probe anti-goat minus (minus strand) plus anti-rabbit antibody (plus strand)] were added and incubated for $1 \mathrm{~h}$ at $37^{\circ} \mathrm{C}$. A negative control was prepared by adding anti-mouse IgG. Fluorescence confocal microscopic images of the cells were acquired using excitation/emission wavelengths of 590/670 nm for the PLA signal and 410/470 $\mathrm{nm}$ for the DAPI (Sigma-Aldrich, St Louis, MO, USA). Images were acquired with a confocal TCS SP8 X microscope (Leica, Wetzlar, Germany) with 40× oil immersion objective. Z-stack image were collected at $0.4 \mu \mathrm{m}$ intervals. The obtained images were processed using Leica LAS X software (Leica, Wetzlar, Germany).

\subsection{Statistical analysis}

Values are expressed as means \pm standard error of means (SEM). Statistical significance of differences in measured variables between control and treated groups was determined by paired $t$-test, one-way ANOVA or two-way ANOVA followed by Bonferroni's multiple comparison tests. The differences were considered to be significant at $p<0.05$.

Supplementary Materials: Supplementary materials can be found at http://www.mdpi.com/1422-0067/20/13/3178/ s1. Figure S1: HDAC inhibitors induced APE1/Ref-1 secretion in HEK293T cells. (A) Effect of HDAC inhibitors on APE1/Ref-1 secretion in HEK293T cells. Cells $(2 \times 105$ cells) were pretreated with trichostatin A (TSA, $1 \mu$ M), SAHA $(0.5 \mu \mathrm{M})$, valproic acid $(1 \mathrm{mM})$, butyrate $(0.5 \mathrm{mM})$ for $1 \mathrm{~h}$, then glyburide $(10 \mu \mathrm{M})$, an ABCA1 transporter inhibitor was treated for $1 \mathrm{~h}$. The total amount of secreted APE1/Ref- 1 in cell-free supernatant was analyzed by ELISA as described in Material and Methods. Column mean $(n=4)$; bars, $S E .^{*} \mathrm{P}<0.05$, significantly different compared with control. \# P $<0.05$, significantly different compared with Basal and glyburide group by one-way ANOVA followed by Bonferroni's multiple comparison test. (B) Effect of glyburide and HDAC inhibitors on the viability of HEK293T cells were determined using a RealTime-GloTM MT luminescent kit. Note: HDAC inhibitors [TSA $(1 \mu \mathrm{M})$, SAHA $(0.5 \mu \mathrm{M})$, valproic acid $(1 \mathrm{mM})$, butyrate $(0.5 \mathrm{mM})]$ used did not significantly affect cell viability.

Author Contributions: Conceptualization, Y.R.L. and B.H.J.; Data curation, Y.R.L., H.K.J., E.O.L., H.S.C., S.C., C.-S.K. and B.H.J.; Formal analysis, Y.R.L., H.K.J., E.O.L. and S.C.; Methodology, H.S.C.; Writing - review \& editing, B.H.J.

Funding: This study was supported by Basic Science Research Program through the National Research Foundation of Korea (NRF) funded by the Ministry of Education (2014R1A6A1029617, 2016R1D1A1B01009752, 2017R1A6A3A11027834, 2016R1A6A3A11932015, 2017R1A6A3A11031769) and a grant from KRIBB Research Initiative Program.

Conflicts of Interest: The authors declare no conflict of interest.

\section{References}

1. Muesch, A.; Hartmann, E.; Rohde, K.; Rubartelli, A.; Sitia, R.; Rapoport, T.A. A novel pathway for secretory proteins? Trends Biochem. Sci. 1990, 15, 86-88. [CrossRef]

2. Pakdel, M.; von Blume, J. Exploring new routes for secretory protein export from the trans-Golgi network. Mol. Biol. Cell 2018, 29, 235-240. [CrossRef] [PubMed]

3. Nugent, M.A.; Iozzo, R.V. Fibroblast growth factor-2. Int. J. Biochem. Cell Biol. 2000, 32, 115-120. [CrossRef]

4. Perillo, N.L.; Pace, K.E.; Seilhamer, J.J.; Baum, L.G. Apoptosis of T cells mediated by galectin-1. Nature 1995, 378, 736-739. [CrossRef] [PubMed]

5. Braddock, M.; Quinn, A. Targeting IL-1 in inflammatory disease: New opportunities for therapeutic intervention. Nat. Rev. Drug. Discov. 2004, 3, 330-339. [CrossRef] [PubMed]

6. Tell, G.; Damante, G.; Caldwell, D.; Kelley, M.R. The intracellular localization of APE1/Ref-1: More than a passive phenomenon? Antioxid. Redox. Signal. 2005, 7, 367-384. [CrossRef] [PubMed] 
7. Tell, G.; Quadrifoglio, F.; Tiribelli, C.; Kelley, M.R. The many functions of APE1/Ref-1: Not only a DNA repair enzyme. Antioxid Redox Signal 2009, 11, 601-620. [CrossRef] [PubMed]

8. Qu, J.; Liu, G.H.; Huang, B.; Chen, C. Nitric oxide controls nuclear export of APE1/Ref-1 through S-nitrosation of cysteines 93 and 310. Nucleic Acids Res. 2007, 35, 2522-2532. [CrossRef]

9. Choi, S.; Lee, Y.R.; Park, M.S.; Joo, H.K.; Cho, E.J.; Kim, H.S.; Kim, C.S.; Park, J.B.; Irani, K.; Jeon, B.H. Histone deacetylases inhibitor trichostatin A modulates the extracellular release of APE1/Ref-1. Biochem. Biophys. Res. Commun. 2013, 435, 403-407. [CrossRef]

10. Park, M.S.; Choi, S.; Lee, Y.R.; Joo, H.K.; Kang, G.; Kim, C.S.; Kim, S.J.; Lee, S.D.; Jeon, B.H. Secreted APE1/Ref-1 inhibits TNF-alpha-stimulated endothelial inflammation via thiol-disulfide exchange in TNF receptor. Sci. Rep. 2016, 6, 23015. [CrossRef]

11. Park, M.S.; Lee, Y.R.; Choi, S.; Joo, H.K.; Cho, E.J.; Kim, C.S.; Park, J.B.; Jo, E.K.; Jeon, B.H. Identification of plasma APE1/Ref-1 in lipopolysaccharide-induced endotoxemic rats: Implication of serological biomarker for an endotoxemia. Biochem. Biophys. Res. Commun. 2013, 435, 621-626. [CrossRef] [PubMed]

12. Nath, S.; Roychoudhury, S.; Kling, M.J.; Song, H.; Biswas, P.; Shukla, A.; Band, H.; Joshi, S.; Bhakat, K.K. The extracellular role of DNA damage repair protein APE1 in regulation of IL-6 expression. Cell. Signal. 2017, 39, 18-31. [CrossRef]

13. Shin, J.H.; Choi, S.; Lee, Y.R.; Park, M.S.; Na, Y.G.; Irani, K.; Lee, S.D.; Park, J.B.; Kim, J.M.; Lim, J.S.; et al. APE1/Ref-1 as a Serological biomarker for the detection of bladder cancer. Cancer Res. Treat. Off. J. Korean Cancer Assoc. 2015, 47, 823-833. [CrossRef] [PubMed]

14. Yoo, D.G.; Song, Y.J.; Cho, E.J.; Lee, S.K.; Park, J.B.; Yu, J.H.; Lim, S.P.; Kim, J.M.; Jeon, B.H. Alteration of APE1/ref-1 expression in non-small cell lung cancer: The implications of impaired extracellular superoxide dismutase and catalase antioxidant systems. Lung Cancer 2008, 60, 277-284. [CrossRef] [PubMed]

15. Lee, Y.R.; Kim, K.M.; Jeon, B.H.; Choi, S. Extracellularly secreted APE1/Ref-1 triggers apoptosis in triple-negative breast cancer cells via RAGE binding, which is mediated through acetylation. Oncotarget 2015, 6, 23383-23398. [CrossRef]

16. Bonaldi, T.; Talamo, F.; Scaffidi, P.; Ferrera, D.; Porto, A.; Bachi, A.; Rubartelli, A.; Agresti, A.; Bianchi, M.E. Monocytic cells hyperacetylate chromatin protein HMGB1 to redirect it towards secretion. EMBO J. 2003, 22, 5551-5560. [CrossRef]

17. Bentovim, L.; Amarilio, R.; Zelzer, E. HIF1 alpha is a central regulator of collagen hydroxylation and secretion under hypoxia during bone development. Development 2012, 139, 4473-4483. [CrossRef]

18. Wang, P.; Keijer, J.; Bunschoten, A.; Bouwman, F.; Renes, J.; Mariman, E. Insulin modulates the secretion of proteins from mature 3T3-L1 adipocytes: A role for transcriptional regulation of processing. Diabetologia 2006, 49, 2453-2462. [CrossRef]

19. Wilkens, S. Structure and mechanism of ABC transporters. F1000Prime Rep. 2015, 7, 14. [CrossRef]

20. Flieger, O.; Engling, A.; Bucala, R.; Lue, H.; Nickel, W.; Bernhagen, J. Regulated secretion of macrophage migration inhibitory factor is mediated by a non-classical pathway involving an ABC transporter. Febs. Lett. 2003, 551, 78-86. [CrossRef]

21. Andrei, C.; Dazzi, C.; Lotti, L.; Torrisi, M.R.; Chimini, G.; Rubartelli, A. The secretory route of the leaderless protein interleukin 1beta involves exocytosis of endolysosome-related vesicles. Mol. Biol. Cell 1999, 10, 1463-1475. [CrossRef] [PubMed]

22. Wein, S.; Fauroux, M.; Laffitte, J.; de Nadai, P.; Guaini, C.; Pons, F.; Comera, C. Mediation of annexin 1 secretion by a probenecid-sensitive ABC-transporter in rat inflamed mucosa. Biochem. Pharm. 2004, 67, 1195-1202. [CrossRef] [PubMed]

23. Hamilton, K.O.; Topp, E.; Makagiansar, I.; Siahaan, T.; Yazdanian, M.; Audus, K.L. Multidrug resistance-associated protein-1 functional activity in Calu-3 cells. J. Pharm. Exp. Ther. 2001, 298, 1199-1205.

24. Legrand, O.; Simonin, G.; Beauchamp-Nicoud, A.; Zittoun, R.; Marie, J.P. Simultaneous activity of MRP1 and Pgp is correlated with in vitro resistance to daunorubicin and with in vivo resistance in adult acute myeloid leukemia. Blood 1999, 94, 1046-1056. [PubMed]

25. Leier, I.; Hummel-Eisenbeiss, J.; Cui, Y.; Keppler, D. ATP-dependent para-aminohippurate transport by apical multidrug resistance protein MRP2. Kidney Int. 2000, 57, 1636-1642. [CrossRef] [PubMed]

26. Hamon, Y.; Luciani, M.F.; Becq, F.; Verrier, B.; Rubartelli, A.; Chimini, G. Interleukin-1beta secretion is impaired by inhibitors of the Atp binding cassette transporter, ABC1. Blood 1997, 90, 2911-2915. 
27. Vrana, D.; Hlavac, V.; Brynychova, V.; Vaclavikova, R.; Neoral, C.; Vrba, J.; Aujesky, R.; Matzenauer, M.; Melichar, B.; Soucek, P. ABC Transporters and their role in the neoadjuvant treatment of esophageal cancer. Int. J. Mol. Sci. 2018, 19, 868. [CrossRef]

28. Jin, S.A.; Lim, B.K.; Seo, H.J.; Kim, S.K.; Ahn, K.T.; Jeon, B.H.; Jeong, J.O. Elevation of serum APE1/Ref-1 in experimental murine myocarditis. Int. J. Mol. Sci. 2017, 18, 2664. [CrossRef]

29. Dai, N.; Cao, X.J.; Li, M.X.; Qing, Y.; Liao, L.; Lu, X.F.; Zhang, S.H.; Li, Z.; Yang, Y.X.; Wang, D. Serum APE1 autoantibodies: A novel potential tumor marker and predictor of chemotherapeutic efficacy in non-small cell lung cancer. PLoS ONE 2013, 8, e58001. [CrossRef]

30. Choi, S.; Shin, J.H.; Lee, Y.R.; Joo, H.K.; Song, K.H.; Na, Y.G.; Chang, S.J.; Lim, J.S.; Jeon, B.H. Urinary APE1/Ref-1: A potential bladder cancer biomarker. Dis. Markers 2016, 2016, 7276502. [CrossRef]

31. Sharff, A.; Fanutti, C.; Shi, J.Y.; Calladine, C.; Luisi, B. The role of the TolC family in protein transport and multidrug efflux-From stereochemical certainty to mechanistic hypothesis. Eur. J. Biochem. 2001, 268, 5011-5026. [CrossRef] [PubMed]

32. Debarbieux, L.; Wandersman, C. Folded HasA inhibits its own secretion through its ABC exporter. EMBO J. 2001, 20, 4657-4663. [CrossRef] [PubMed]

33. Backhaus, R.; Zehe, C.; Wegehingel, S.; Kehlenbach, A.; Schwappach, B.; Nickel, W. Unconventional protein secretion: Membrane translocation of FGF-2 does not require protein unfolding. J. Cell Sci. 2004, 117, 1727-1736. [CrossRef] [PubMed]

34. Nickel, W. The unconventional secretory machinery of fibroblast growth factor 2. Traffic 2011, 12, 799-805. [CrossRef] [PubMed]

35. Tarling, E.J.; de Aguiar Vallim, T.Q.; Edwards, P.A. Role of ABC transporters in lipid transport and human disease. Trends Endocrinol. Metab. 2013, 24, 342-350. [CrossRef] [PubMed]

36. Neufeld, E.B.; Remaley, A.T.; Demosky, S.J.; Stonik, J.A.; Cooney, A.M.; Comly, M.; Dwyer, N.K.; Zhang, M.; Blanchette-Mackie, J.; Santamarina-Fojo, S.; et al. Cellular localization and trafficking of the human ABCA1 transporter. J. Biol. Chem. 2001, 276, 27584-27590. [CrossRef]

37. Bhakat, K.K.; Izumi, T.; Yang, S.H.; Hazra, T.K.; Mitra, S. Role of acetylated human AP-endonuclease (APE1/Ref-1) in regulation of the parathyroid hormone gene. EMBO J. 2003, 22, 6299-6309. [CrossRef]

38. Jackson, E.B.; Theriot, C.A.; Chattopadhyay, R.; Mitra, S.; Izumi, T. Analysis of nuclear transport signals in the human apurinic/apyrimidinic endonuclease (APE1/Ref1). Nucleic Acids Res. 2005, 33, 3303-3312. [CrossRef]

39. Barnes, P.J.; Adcock, I.M.; Ito, K. Histone acetylation and deacetylation: Importance in inflammatory lung diseases. Eur. Respir. J. 2005, 25, 552-563. [CrossRef]

40. Soe, N.N.; Sowden, M.; Baskaran, P.; Kim, Y.; Nigro, P.; Smolock, E.M.; Berk, B.C. Acetylation of cyclophilin $\mathrm{A}$ is required for its secretion and vascular cell activation. Cardiovasc. Res. 2014, 101, 444-453. [CrossRef]

41. Li, Y.; Alam, H.B. Modulation of acetylation: Creating a pro-survival and anti-inflammatory phenotype in lethal hemorrhagic and septic shock. J. Biomed. Biotechnol. 2011, 2011, 523481. [CrossRef] [PubMed]

42. Lee, K.M.; Lee, E.O.; Lee, Y.R.; Joo, H.K.; Park, M.S.; Kim, C.S.; Choi, S.; Jeong, J.O.; Jeon, B.H. APE1/Ref-1 inhibits phosphate-induced calcification and osteoblastic phenotype changes in vascular smooth muscle cells. Int. J. Mol. Sci. 2017, 18, 2053. [CrossRef] [PubMed]

43. Joo, H.K.; Lee, Y.R.; Lee, E.O.; Park, M.S.; Choi, S.; Kim, C.S.; Park, J.B.; Jeon, B.H. The extracellular role of Ref-1 as anti-inflammatory function in lipopolysaccharide-induced septic mice. Free Radic. Biol. Med. 2019, 139, 16-23. [CrossRef] [PubMed]

44. Schunke, S.; Stoldt, M.; Novak, K.; Kaupp, U.B.; Willbold, D. Solution structure of the Mesorhizobium loti K1 channel cyclic nucleotide-binding domain in complex with cAMP. EMBO Rep. 2009, 10, 729-735. [CrossRef] [PubMed]

45. Lee, Y.R.; Lim, J.S.; Shin, J.H.; Choi, S.; Joo, H.K.; Jeon, B.H. Altered secretory activity of APE1/Ref-1 D148E variants identified in human patients with bladder cancer. Int. Neurourol. J. 2016, 20, S30-S37. [CrossRef] [PubMed]

46. Yamamori, T.; DeRicco, J.; Naqvi, A.; Hoffman, T.A.; Mattagajasingh, I.; Kasuno, K.; Jung, S.B.; Kim, C.S.; Irani, K. SIRT1 deacetylates APE1 and regulates cellular base excision repair. Nucleic Acids Res. 2010, 38, 832-845. [CrossRef] [PubMed]

(C) 2019 by the authors. Licensee MDPI, Basel, Switzerland. This article is an open access article distributed under the terms and conditions of the Creative Commons Attribution (CC BY) license (http://creativecommons.org/licenses/by/4.0/). 